Article

\title{
Eliciting a Sense of Normativity in Derrida through Honneth's Theory of Recognition
}

Roland Theuas DS. Pada

\begin{abstract}
In this paper, I will attempt to explore the problem of normativity vis-à-vis the condition of subjectivity as an irreducible "Other." The focal point of this paper is to explore Derrida's essay Violence and Metaphysics and elicit the possibility of acquiring a normative sense of ethics in the light of his turn towards Levinas' philosophy. With this I intend to lay down the fundamental issues regarding subjectivity and objectivity via Honneth's theory of recognition. At the end of this paper, I will propose the possibility of reaching an equilibrium within the issue of subjective and objective norms.
\end{abstract}

Keywords: Derrida, Honneth, normativity, theory of recognition

\section{Introduction}

7 he particularity of an individual has never failed to elicit the tolerance that we have often associated with justice. In the conception of a normative practice, we find that the strength of subjective experience by the particularity of an individual drives us to create exemptions and even bridge the gulf between objective normative values and subjective particular values. The danger that we face in these times is to fall prey to the proliferation and accessibility of individual particularity when it comes to subjective values. The increasing ease in which subjectivity is proliferated is heralded by the growing advances of technologies that allow individuals to project subjectivities to social spheres. We cannot help but acknowledge the fact that individuality and social fragmentation is becoming more ubiquitous; though it may have to conform to prevailing structures of transmission from existing norms and social practices, the possibility in which an individual subjectivity is proliferated has very little social, economic, and political resistance as opposed to the past decades that we have experienced.

(c) 2015 Roland Theuas DS. Pada

http://www.kritike.org/journal/issue 16/pada june2015.pdf

ISSN 1908-7330 
Axel Honneth's theory of recognition provides us with the mechanism for understanding how the equilibrium between subjectivity and objective normative values are reached and at the same time disrupted. These normative values do not supervene social practices of ideologies and recognition of values. They are, as Honneth asserts, quasi-transcendental normative principles. This quasi-transcendental nature of Honneth's sense of normativity can be further appreciated through the appropriate understanding of normativity through the underpinnings of metaphysics as a semi-fixed system of values to which the telos of ethics can be guided accordingly. The difficulty of articulating this can be seen in the tone of the Honneth's readers; for example, in the case of Kompridis, normativity poses a problem towards the understanding of recognition primarily because he thinks that recognition can be an instrumental force that imposes identity through normativity. ${ }^{1}$

My assertion is that Kompridis is unable to see past the problem of Honneth's theory of recognition in a broader trajectory. Though I agree with Kompridis' statement that recognition is over-burdened by a multitude of social and political demands, ${ }^{2}$ I argue that these problems arise as a consequence of over-valorising subjectivities to the extent that they become detrimental to the autonomous social cohesion due to social fragmentation. Furthermore, the current trend in philosophical research leans towards disdaining or rejecting "metaphysical" conceptions of normative values in as much as they are restrictive and oppressive to identities. Following the posthumanist and post-structuralist narratives, there is a strong rejection of fixed and over-arching principles that elicit a metaphysical sense of normativity.

My goal in this paper re-affirm the ontological and perhaps the metaphysical quality of normativity, which I think is gravely misunderstood in the criticisms against Honneth's recognition theory. To do this, I turn back to Derrida's reading of Levinas' Totality and Infinity in the essay Violence and Metaphysics. I have three reasons to explore these connections: (1) firstly, among the critical philosophies available, Derrida's critique of metaphysics provides an even-handed take on normativity, not only as a linguistic product, but also as an ethical system. I have argued elsewhere that Derrida's critique of ontology is through the opposition between ipseity and difference, that is to say, that there is a constant erasure and retention of metaphysics within any system of normativity. ${ }^{3}$ In Derrida's jargon, the notion of the trace serves as an important reminder that metaphysics is meaningful only in so

\footnotetext{
${ }^{1}$ Nikolas Kompridis, "Struggling over the meaning of recognition," in European Journal of Political Theory, 6:277 (2007), 286-287.

${ }^{2}$ Ibid.

3 Roland Theuas Pada, "The Paradox of Ipseity and Difference: Derrida's Deconstruction and Logocentrism," Kritike, 1:1 (2007), 45-46.
}

(c) 2015 Roland Theuas DS. Pada http://www.kritike.org/journal/issue 16/pada june2015.pdf ISSN 1908-7330 
far as it is a product of always already existing and at the same time the 'yetto-come.' Simply put, understanding the quality of normativity as a metaphysical product necessarily entails that it is coming from already existing epistemic structures that are stable enough to bring forth a sense of social coherence, and yet at the same time provide ample room for revision, adjustment, and critique. (2) Secondly, Honneth turns back to Derrida's discussion of asymmetry in this particular essay to emphasise the importance of subjective experience in realising change within normative practices to which recognition becomes possible, particularly, in the notion of friendship. ${ }^{4}$ Honneth adopts this stance in his current work, initially as a revision of his use of Herbert Mead's philosophical anthropology, ${ }^{5}$ and later on adopting it as an immanent foundation for institutions that reproduce norms. ${ }^{6}$ In doing this, Honneth is able to fill in the gap left by the assumption of love as the hypothetical origin of institutions in the family, which is by no means a very limited perspective of institutions that may not necessarily represent the genesis of contemporary institutions. (3) The last reason for this is that Honneth himself acknowledges a closer affinity to the productive discussion of normativity towards Derrida's take on the economics of ethics. ${ }^{7}$

The position of this paper is that Honneth's recognition theory is cyclical in a sense that normativity ought to be understood as the end and the beginning of recognition. Honneth's affirmation of social cohesion in the form of cooperative individualism ${ }^{8}$ highlights his emphasis on individuation that is deeply anchored towards the value that is generated within an already existing social structure. This provides Honneth a somewhat stable ground to which the frivolous and tempestuous nature of individuation becomes tempered with existing normative values, thus, avoiding the antisocial and schizoidal tendencies of anarchism. The dynamics invested upon the theory of recognition allows a greater sense of normative flexibility without derailing the fundamental importance of individuation in the realisation and fulfilment of freedom. By providing an immanent critique from within existing social structures, ${ }^{9}$ norms acquire an adequate sense of stability and at the same time provide individuals room to resolve conflict through the revision of normative values that are no longer practical or desirable.

\footnotetext{
${ }^{4}$ Axel Honneth, Disrespect: The Normative Foundation of Critical Theory, trans. by Joseph Ganahl (UK: Polity Press, 2007), 217-218.

${ }^{5}$ Goncalo Marcelo, "Recognition and Critical Theory Today: An Interview with Axel Honneth," in Philosophy and Social Criticism, 39 (2013), 210.

${ }^{6}$ Axel Honneth, Freedom's Right, trans. by Joseph Ganahl (UK: Polity Press, 2014), 136138.

${ }^{7}$ Marcelo, "Recognition and Critical Theory Today," 217.

8 Ibid.

${ }_{9}$ Axel Honneth, "The Normativity of Ethical Life," trans. by Felix Koch, in Philosophy Social Criticism, 40 (2014), 824.

(C) 2015 Roland Theuas DS. Pada

http://www.kritike.org/journal/issue 16/pada june2015.pdf

ISSN 1908-7330

(c) BY-NC-ND
} 
My turn to Derrida is likewise tempered by this position; in his reading of Levinas' work, Derrida presents the extremes in which a normative reconstruction may take place within the trajectories of Levinasian ethics. I see a very strong analogue in Derrida's pronouncement of the inescapable disposition of ethics with metaphysics between Honneth's idea of normativity and individual subjectivity. The tension that is seen with these concepts is the inevitability of ethics to function with metaphysics, ${ }^{10}$ as somewhat similar to the idea of individual recognition without norms and social institutions.

\section{Derrida's Productive Undertaking of Ethics and Metaphysics}

Derrida's "Violence and Metaphysics"11 lays out this problem of subjectivity both as the condition and possibility of ethics. This work presents a working solution of how Levinas' Totality and Infinity could be read amidst its denial of metaphysics, which despite Derrida's incisive critique, articulates Levinas' intention of emphasizing the importance of ethics and difference. A notable motif also appears in this work as Derrida continues to take his reading of Levinas under the three $\mathrm{H}^{\prime}$ s of philosophy, namely, Hegel, Husserl, and Heidegger. This long essay begins with an enigmatic lament, which perhaps, is directed towards the state of philosophy and metaphysics. This long passage is worth recalling in this discussion:

That philosophy died yesterday, since Hegel or Marx, Nietzsche, or Heidegger-and philosophy should still wander toward the meaning of its death-or, that it has always lived knowing itself to be dying; that philosophy died one day, within history, or that it has always fed on its own agony, on the violent way it opens history by opposing itself to nonphilosophy, which is its past and its concern, its death and wellspring; that beyond the death, or dying nature, of philosophy, perhaps even because of it, thought still has a future, or even as is said today, is still entirely to come because of what philosophy has held in store; or more strangely still, that

${ }^{10}$ To clarify, my persistent use of metaphysics as a preference over ontology is a conscious one. No matter how hard we work out the differences, an ontology will always find its function as a metaphysical one insofar as an ontology needs to press its assertion as if it were a stable presence. Otherwise, the risk of the inability to talk about 'beings' in a stable form will make any theoretical assertion fleeting and futile.

${ }^{11}$ Cf. Jacques Derrida, "Violence and Metaphysics," in Writing and Difference, trans. by Alan Bass (London: Routledge Classics, 2001).

(c) 2015 Roland Theuas DS. Pada

http://www.kritike.org/journal/issue 16/pada june2015.pdf

ISSN 1908-7330

(cc) BY-NC-ND 
the future itself has a future-all these are unanswerable questions ... It may even be that these questions are not philosophical, are not philosophy's questions. Nevertheless, these should be the only questions today capable of founding the community, within the world, of those who are still called philosophers; and called such in remembrance, at very least, of the fact that these questions must be examined unrelentingly, despite the diaspora of institutes and languages, despite the publication and techniques that follow on each other procreating and accumulating by themselves, like capital or poverty. ${ }^{12}$

Through his reading, Derrida analyses the fundamental flaw of Levinasian ethics that is rooted in its critique of metaphysics. As a critique of philosophical telos, Derrida reflects on philosophy as a form of science that cannot project the actual of the future with accuracy. What he finds lamentable is that in this projection of futural possibilities, responsibility is often neglected as an other of possibilities. The figurative use of philosophy, as if it was a person or an individual, is characterised by the ethos of responsibility that points to it as both the victim and the responsible party for violence. The question of possibilities in philosophy is metaphysical, insofar as it is oriented towards an anticipatory discourse of what is to come after its projections; thus, ultimately, making it responsible for the consequences of its discourse. Going back to Heidegger's question of originary import- "why are there beings at all instead of nothing?"13 - brings us to the realisation that existence is always an already existing pre-condition of philosophy. In this case, we find the existing temporal conditions of understanding being rooted to a sense of historicity, a historicity that entraps us with the impotent capacity to retrieve a lost past and look forward to an uncertain future. The question of ethics and the question of being present a tension that Derrida finds in Hegel and is divided on opposite poles in Husserl and Heidegger. ${ }^{14}$ Husserl, through his phenomenological approach, was depicted as a gentler and more subordinated reception towards being. Heidegger is seen as a transgressor of being; through his ontological emphasis of grasping being,

\footnotetext{
${ }^{12}$ Derrida, "Violence and Metaphysics," 97-98.

${ }^{13}$ Martin Heidegger, Introduction to Metaphysics, trans. by Gregory Fried and Richard Polt (Yale University Press, 2000), 1.

${ }^{14}$ Derrida, "Violence and Metaphysics," 100.

(C) 2015 Roland Theuas DS. Pada http://www.kritike.org/journal/issue 16/pada june2015.pdf

ISSN 1908-7330
}

(c) BY-NC-ND 
Dasein is obligated to be always ahead-of-itself, ${ }^{15}$ which is aptly depicted in the idea of Vorlaufenheit.

Husserl and Heidegger, despite their faults, were for Derrida cognisant of the fact that these emphases on tradition and approximation had to be met in a shifting sense of balance that had to produce a productive discourse. Derrida aptly refers to this shifting sense of balance as an economy. ${ }^{16}$ Moving further into Derrida's reading of Levinas, the issue of metaphysics as an inherently violent mechanism of normativity is pitted with this dilemma of productivity. On one hand, if metaphysics takes a position that imposes its will on the Other, (the marginalised, misaligned, meek, and misappropriated), the Other is alienated and it becomes inevitably the receiving end of violence. On the other hand, if the Other is taken as a superior, an Other that we cannot speak of but only speak to, ${ }^{17}$ the Other that is infinitely exterior to me, ${ }^{18}$ we risk the violence of hesitation. ${ }^{19}$ The issue of productivity in Levinas had some solutions to these problems as Derrida notes; for example, the analogue between man and god imposes a theological premise in order for ethics to be over and above metaphysics. ${ }^{20}$ Believers of theological premises of ethics would find this moral imperative very attractive to the extent that normativity can be elicited without the force of coercion with the exception, of course, of teleological ends that are not stated explicitly within the norm. ${ }^{21}$ Regardless of the belief system in a theologically inclined telos of normativity, both believers and non-believers ought to look at the benefit of finding some sense of moral stability within the framework of theology or religion. It is through this theological limit that we are able to recognise the condition in which human subjectivity is understood in its infinity, not in a positive sense of certitude, but rather in a negative epistemic sense. The infinity of the Other is not a positive existential infinity. Death lingers as a constant possibility for the Other as well as ourselves. The Other is infinite because of its dialectical asymmetry. ${ }^{22}$ The Other is unknowable in its totality for two reasons. The first is because of its interiority that is never revealed in totality; we only know the Other insofar as it reveals itself in its manifestations through which we have a trace of its interiority, which can be distorted by language, culture, aesthetic sensibilities, etc. Second, another

${ }_{15}$ Martin Heidegger, Being and Time, trans. by Joan Stambaugh (New York: State University of New York Press, 1996), 310.

${ }^{16}$ Derrida, "Violence and Metaphysics," 100.

17 Ibid., 128.

18 Ibid., 139.

${ }^{19}$ Ibid., 184.

${ }^{20}$ Ibid., 134.

${ }^{21}$ For example, the use of indulgences to build lavish and expensive cathedrals, or perhaps to promote a social condition beneficial to the theological institution.

${ }^{22} \mathrm{Ibid} ., 133$.

(C) 2015 Roland Theuas DS. Pada

http://www.kritike.org/journal/issue 16/pada june2015.pdf

ISSN 1908-7330 


\section{0}

ELICITING A SENSE OF NORMATIVITY

source to which we can appropriate a negative sense of infinity is the limits to which our epistemic certainty of possibility is faced with uncertainty when it comes to the possibilities that might befall the Other. This is where we are able to criticise and even elevate the understanding of metaphysics as a possible source of violence. Likewise, if we were to take Derrida's stance of the double-gesture, we could also see the possibility in which an emancipatory discourse is able to liberate the Other from violence through the criteria set by already existing norms.

The point of the matter is that the essential difference between our objective and subjective norms is nevertheless subject to the varying flexibility and stability found in the metaphysics of ethics. The productive discourse of ethics in Derrida provides a practical and realistic understanding of how ethics could be grounded on moral principles that is already in practice by revealing its limited epistemological underpinnings that can result in violence. The need for stable foundation for ethical and moral criteria serves a functional purpose that cannot be denied in the perspective of theology. This stable foundation is only a springboard to understand a more fundamental basis for normative ethics, for no matter how we turn back to a theological principle, our practical ascent towards these metaphysical principles will be subject to the contrasting values experienced within the norms of practical life. It is worth mentioning here that Hegel, despite his obsession with the development of the objective spirit, looks at the ethical world as one that is abandoned by god, ${ }^{23}$ to which Hegel pronounces that the ethical life ought to be realised outside the confines of the divine. Though it is difficult to conceive the possibility of finally seeing the owl of Minerva flapping its wings at dusk, we must not take it for granted that the movement of ethics towards the realisation of its telos ought to be made by human subjects.

To which direction can we turn then? The understanding of our moral circumstance moves us to a relevant understanding of social relations as a supervening norm - that morality, regardless of its metaphysical or theological origin, depends entirely on the bonds of society that gives meaning towards its enactment. Derrida, in his effort to salvage the problematic disavowal of metaphysics in Levinas, points out the following fundamental issues in understanding ethics and its entwinement towards metaphysics. (1) Ethics, in the sense of metaphysics, is only meaningful and productive when it is understood as a noema. ${ }^{24}$ As a system that brings normativity into practice, ethics has to provide a relatively stable ground to guide and direct actions of social interactions. Without this stable framework,

\footnotetext{
${ }^{23}$ G.W.F. Hegel, Philosophy of Right, trans. by S.W. Dyde (Ontario: Batoche Books Ltd., 2001), 13.

${ }^{24}$ Derrida, "Violence and Metaphysics," 152.
}

(C) 2015 Roland Theuas DS. Pada

http://www.kritike.org/journal/issue 16/pada june2015.pdf

ISSN 1908-7330

(c) $)$ BY-NC-ND 
ethics becomes useless since it will not be able to provide room for dispute within society. If individuating values take an ahistorical perspective, disregarding established norms and ethical principles, then all values would be lost because they will immediately become insignificant to a totally external Other. (2) The relative stability of metaphysics is an economy of difference. The reason that I think Derrida uses this concept is that economics, insofar as it intends to reproduce itself in any social discourse, has to undergo a constant series of revision to achieve its stable and productive ground. The success that we see in the immanent auto-critique of capitalism holds this reference towards economics as a meaningful one, that despite its selfcontradictions, the economic force of capitalism allows it to adjust and maintain stability within its structure. Ethics, as an economy of difference, holds the human subjects and objects of ethics as active participants within its reproduction.

Ethics then is not simply a normative principle with its subjects and objects blindly conforming to a metaphysical telos. The will to transform and shape the normative grounds of ethics lies precisely in the economic function of violence. Violence here is not in the purest sense of violence as an absolute form of transgression of the Other; it is a violence that is necessary for us to pursue a ground for recognising Otherness. Violence is something that we need to acknowledge in order to reconcile the objective forms of values to subjective ones, just as we will acknowledge that the Other has to be spoken of in order to be receptive to the Other.

\section{Eliciting Normativity through Difference}

To begin with, Honneth's sense of normativity is social; this is much pronounced with his adoption of Hegel's Sittlichkeit. As opposed to ideology, Honneth's perspective takes normativity as a product of interplay between societies and individuals, with the consideration that society is an always already given. Ideologies, on the other hand, take root in an individual perspective that can take the shape of normativity when it is disseminated and consumed socially and institutionally. In this sense, we can say that the difference between Honneth's critical theory, as opposed to let us say Slavoj Zizek's, is that the former is concerned with the looping effect of normativity from social relations towards the individual, then back again towards the individual once more. The latter differs insofar as the approach towards understanding the normative effects of ideology and how it evolves becomes manipulated, or to a certain extent, perverted, is quite linear. This difference is articulated by the tone of the works that they produce; Honneth is much inclined to move towards social transformation from within social relations

(c) 2015 Roland Theuas DS. Pada

http://www.kritike.org/journal/issue 16/pada june2015.pdf

ISSN 1908-7330

(cc) BY-NC-ND 


\section{2}

ELICITING A SENSE OF NORMATIVITY

and institutions, while Zizek may tend toward a tempered and critical form of revolution.

Derrida's sense of difference allows us to elicit a clearer sense of normativity in Honneth as much as we would benefit from Honneth's sense of normativity in understanding the direction of ethics in Derrida's difference. The adoption of receptivity and openness towards the Other from Levinas' ethics provides Derrida a strong normative foundation in understanding social relations as a productive negotiation. The receptivity towards the other is justified insofar as it provides a foundation for social relations, which in turn, serves as the starting and continuous selfreproduction of normativity. Difference as an essential normative feature of ethics reverberates the oscillating function of ethical principles that is found in Hegel's ethical life; it is stable and self-adjusting insofar as it adapts to immanent fluctuations of subjectivities within the social sphere. This ethical turn in Derrida's writings is adapted in his latter works that question the status of relations in friendship ${ }^{25}$ as well as social and institutional responsibility. 26

Honneth's appropriation of intersubjectivity as a receptive openness to individual differences is a comprehensive way of addressing social reproduction through the mechanism of normativity. Through this perspective, it is possible to address the question of the origin of social relations through normativity and at the same time diagnose social pathologies that generate domination and violence. Honneth's agenda of providing a critique of already institutionalised norms and how our social practices are informed through their deployment ${ }^{27}$ gains epistemic clarification through the understanding of difference. A word of caution, however, is required. Difference in Derrida's writings does not simply refer to individuation through the irreducibility of subjectivity. Difference ought to be taken as a product of similarity as a stabilising principle. These mechanisms of difference contribute to the relative stability and flexibility of metaphysical concepts. These concepts are still anchored to a historicity and are open to transformative or creative appropriations of individualised interpretations. The difficulty that a reader of Honneth's works faces is understanding the difference in which normativity takes place. In Ricoeur's The Course of Recognition, Honneth's idea of normativity is falsely accused as a product of struggle to which more "peaceful experiences of recognition"

${ }^{25}$ Cf. Jacques Derrida, The Politics of Friendship, trans. by George Collins (London: Verso, 2006), 271.

${ }^{26}$ Cf. Jacques Derrida, Ethics, Institutions, and the Right to Philosophy, trans. by Peter Pericles Trifonas (Boston: Rowman and Littlefield Publishers, Inc., 2002), 14-17.

${ }^{27}$ Marcelo, "Recognition and Critical Theory Today," 216.

(C) 2015 Roland Theuas DS. Pada

http://www.kritike.org/journal/issue 16/pada june2015.pdf

ISSN 1908-7330

(c) $)$ BY-NC-ND 
can be substituted. ${ }^{28}$ By taking the idea of "struggle" quite literally, Ricoeur accuses Honneth's model of recognition as a possible source of "bad infinity"; particularly, when norms over-impose a great objective ideal in which the subject has no power or capacity of attaining. ${ }^{29}$ Ricouer's criticisms serve as an important nuance that we can learn from Derrida's "Violence and Metaphysics." That violence, in the case of metaphysics, is not absolutely and necessarily as infinitely demanding in the positive sense. The sense of demand from the Other is a negative infinity in which the subject is epistemologically hampered by its own recognition of the Other as a possibility. In other words, objectivity is never taken as an absolute criterion for normative expectations. The same warning is given by Honneth in his essay on the normativity of the ethical life, which discourses on normativity should steer clear of Hegel's philosophy of the spirit.30 The teleological trajectory of normativity is not meant to be understood as an absolute objective end that can be projected or plotted; rather, it is a continuous process of progressive change through which the workings of normativity ought to be understood. Thus, in this sense, struggles for recognition ought to be understood not as struggles in which violence in its absolute form takes place. Struggles for recognition ought to be interpreted as moments in history that attempt to shift the trajectories of norms toward the direction that is accepted by subjective experiences.

\section{Normativity and Recognition}

The task of understanding recognition is under the heavy scrutiny of subjectivity insofar as it is deeply anchored on the shifting values of norms established by social practices. Furthermore, the greater the level of social complexity girded by increasing the population and technologies that proliferate subjectivities, the more it requires a cautious approach in deploying recognition as a productive critique of normativity. Ricouer's attempt, for example, to provide a lexical understanding of recognition ${ }^{31}$ runs short of disclosing actual instances of recognition since it fails to acknowledge the complexity of synchronic and diachronic use of recognition. Belabouring the actual meaning of recognition becomes the theme of his work insofar as the idea of normativity is seen as a broad and encompassing principle that undergirds the structure of social relations. Normativity, for one, is not simply observed in an institutional level to which rights are seen in a firm

${ }^{28}$ Paul Ricoeur, The Course of Recognition, trans. by David Pellauer (London: Harvard University Press, 2005), 186.

${ }^{29}$ Ibid., 218.

${ }^{30}$ Axel Honneth, "The Normativity of Ethical Life," 808.

${ }^{31}$ Ricouer, The Course of Recognition, 1-21.

(c) 2015 Roland Theuas DS. Pada

http://www.kritike.org/journal/issue 16/pada june2015.pdf

ISSN 1908-7330

(cc) BY-NC-ND 


\section{ELICITING A SENSE OF NORMATIVITY}

legal and juridical definition. Legal rights, as a normative prescription, provide a stable principle in which norms have a rigid enactment of rights. The limitation of this, however, is that it does not inform us of actual social practices that are already deployed by social interactions, regardless of whether it is supported by norms that are imposed by laws and rights.

I argue that Honneth's recognition theory is the realisation of norms in the individual through which the practice and critique of norms become possible. While it is possible to fixate and alter norms, it is also implicit that norms ought to have a historicity in which their practice takes place in an already given context. The productive aspect of recognition begins when one is able to realise that norms are off-tangent from an individual's expectation or actual practice in social relations. The ability to change and alter norms has to be tempered by the condition in which norms are accepted and recognised. One has to 'struggle' through existing social practices that can lead society to the understanding that the norm in practice is no longer true to its teleological aims. Honneth's discussion of Hobbes and Machiavelli is an account of how subjectivities began to gain a stronger foothold in rapidly changing social structures from Medieval to Modern European societies. We can account for two factors that led to the recognition of subjectivities in Honneth's reading of Hobbes and Machiavelli. Firstly, the change in the method of manufacturing, specifically, publishing, gave rise to the influx of thoughts and ideas through innovations in printing. ${ }^{32}$ The second factor comes in the form of the realisation of selfishness and egotism as a general disposition of individuals ${ }^{33}$ to which a greater power or political force has to tame and curb in order to maintain a relative sense of social cohesion. This cycle of hegemony, however, is not practical in the sense of maintaining power through force or coercion.

Honneth's recourse to Hegel's notion of the ethical life provides a more productive way of assessing and recognising social structures that inform normative practices. Resolving and disputing normative structures through leaders and violence is not only impractical, it is also improbable insofar as it forgets the fundamental fact that autonomy and freedom are pervasive human factors that have to be accounted in every normative social structure. Through Hegel, Honneth aims to achieve an explanation of the possibility of an ethically integrated community of free social subjects. ${ }^{34}$ This has been a consistent theme from his early works up to his most current writings, such as Freedom's Right. The issue with this Hegelian theme, however, is how Honneth can explain the origin or genesis of the ethical life.

32 Axel Honneth, Struggle for Recognition, trans. by Joel Anderson (Massachusetts: The MIT Press, 1995), 8.

${ }^{33}$ Ibid.

${ }^{34}$ Ibid., 13.

(C) 2015 Roland Theuas DS. Pada

http://www.kritike.org/journal/issue 16/pada june2015.pdf

ISSN 1908-7330

(c) $)$ BY-NC-ND 
The three spheres of recognition initially formed a quasi-historical account of how norms are gradually introduced and participated upon by individuals within society. A general theme that Honneth also adopts from Hegel is the function of recognition to provide a negative dialectic of self-realisation through social interactions. For Hegel, the realisation of the self is objectively reached only insofar as it suppresses its own self in the recognition that its objective form is neither complete with its self nor is it complete with the Other. ${ }^{35}$

The self, insofar as it is historically situated, has to integrate itself to existing norms in order to work its way to recognise and be recognised by the social structure. The difficulty of proposing a genesis or a quasitranscendental framework is realised when Honneth adopts G.H. Mead's philosophical anthropology. The three spheres of recognition have to start with a fundamental ground in which intersubjective receptivity occurs without any recourse to self-interest and egotism, namely, in the sphere of the family. The development of the concept of an ' $\mathrm{I}$ ' is in itself a struggle to situate the 'me' in the three spheres. The sphere of love, for example, begins with the family and the child's relationship in which the child, as a starting point, is received with open receptivity. The child at this stage recognises itself through the negativity that occurs between itself as a 'me' and that of the interest of the family or the primary caregiver. To note, despite the open receptivity, the struggle for recognition presents itself when the child realises the presence of normative structures within the social unit of the family. ${ }^{36}$ The normative process of individuation is immediately realised when the child becomes aware of his difference and his need to have his difference recognised by the immediate social environment. As I have pointed out earlier, this situation need not be limited to the function of social units such as the family; it can extend to less formal social groups to nations accepting strangers or foreigners from their culture with open receptivity to gradually integrate them as participants of social norms. Differences in individual subjectivities contribute to the formation and reproduction of norms insofar as they either affirm or point out pathological problems in the practiced norms that are given societal and institutional force. In this sense, the claim for rights which later on leads to its realisation as esteem is epistemically founded on norms that issue a legitimate rapport to recognition in an objective and subjective level.

${ }^{35}$ G.W.F. Hegel, Phenomenology of the Spirit, trans. by A.V. Miller (New York: Oxford University Press, 1977), 111.

${ }^{36}$ Honneth, Struggle for Recognition, 101.

(C) 2015 Roland Theuas DS. Pada

http://www.kritike.org/journal/issue 16/pada june2015.pdf

ISSN 1908-7330

(cc) BY-NC-ND 


\section{6 \\ ELICITING A SENSE OF NORMATIVITY}

\section{Conclusion}

As a consolation, Honneth does retain an imperative observed in the work of Levinas and continued through Derrida's appropriation. Love as an important intersubjective starting point of social relations pervades regardless of whether it may exist for norms or against norms. One can only imagine that the struggle for recognition itself is rooted in the desire of individual subjects to be recognised and be once more integrated into society as a desire to be united with the condition of normativity. Needless to say, struggles towards recognition are already conditioned by the fact that parties that aim towards the change of normative structures are also attempting to shape normativity to be once more integrated within society. In conclusion, one can understand that individuality is an essential component that prevents normativity from becoming violent insofar as its stability is entirely dependent on social cohesion. Likewise, social cohesion improves the state in which normativity reaches an equilibrium that sustains its own selfreproduction. Honneth's theory of recognition accounts for Derrida's ethics of difference insofar as difference is what makes recognition possible; without difference, the possibility of establishing norms from a practical and historical perspective becomes impossible. In the same line, the lack of difference also robs us of the ability to critically assess and re-orient the trajectories of objectified norms.

Department of Philosophy and the Graduate School, University of Santo Tomas, Philippines

\section{References}

Derrida, Jacques, "Violence and Metaphysics," in Writing and Difference, trans. by Alan Bass (London: Routledge Classics, 2001). Ethics, Institutions, and the Right to Philosophy, trans. by Peter Pericles Trifonas (Boston: Rowman and Littlefield Publishers, Inc., 2002).

The Politics of Friendship, trans. by George Collins (London: Verso, 2006).

Hegel, G.W.F., Phenomenology of the Spirit, trans. by A.V. Miller (New York: Oxford University Press, 1977). Philosophy of Right, trans. by S.W. Dyde (Ontario: Batoche Books Ltd., 2001).

Heidegger, Martin, Being and Time, trans. by Joan Stambaugh (New York: State University of New York Press, 1996).

(C) 2015 Roland Theuas DS. Pada

http://www.kritike.org/journal/issue 16/pada june2015.pdf

ISSN 1908-7330

(c) BY-NC-ND 
Introduction to Metaphysics, trans. by Gregory Fried and Richard Polt (Yale University Press, 2000).

Honneth, Axel, "The Normativity of Ethical Life," trans. by Felix Koch, in Philosophy Social Criticism, 40 (2014).

Disrespect: The Normative Foundation of Critical Theory, trans. by Joseph Ganahl (UK: Polity Press, 2007).

Freedom's Right, trans. by Joseph Ganahl (UK: Polity Press, 2014).

Struggle for Recognition, trans. by Joel Anderson (Massachusetts: The MIT Press, 1995).

Kompridis, Nikolas, "Struggling over the meaning of recognition," in European Journal of Political Theory, 6:277 (2007).

Marcelo, Goncalo, "Recognition and Critical Theory Today: An Interview with Axel Honneth," in Philosophy and Social Criticism, 39 (2013).

Pada, Roland Theuas, "The Paradox of Ipseity and Difference: Derrida's Deconstruction and Logocentrism," Kritike, 1:1 (2007).

Ricoeur, Paul, The Course of Recognition, trans. by David Pellauer (London: Harvard University Press, 2005). 